\title{
Interaction effects of corporate hedging activities for a multi-risk exposure: evidence from a quasi-natural experiment
}

\author{
Markus Hang ${ }^{1}$ (D) . Jerome Geyer-Klingeberg ${ }^{1} \cdot$ Andreas W. Rathgeber $^{1}$. \\ Clémence Alasseur ${ }^{2} \cdot$ Lena Wichmann $^{1}$
}

Published online: 12 July 2020

(C) The Author(s) 2020

\begin{abstract}
This study analyzes the interaction effects of corporate hedging activities of electric utility firms facing a manifold risk exposure consisting of several market price risks. We employ 16 recent introductions of markets for trading electricity derivatives as a quasi-natural experiment. The results show that electric utilities generally favor domestic markets for trading electricity derivatives, which might be reduced to their usual high market power and the related good predictability of electricity prices. As a consequence, electricity output hedging eliminates a major part of overall market risk. Further, we identify several spillover effects of electricity output hedging: The sensitivities to input commodity prices decrease, while the sensitivities to foreign exchange rates and interest rates increase. Furthermore, electricity output hedging increases debt capacities and the availability of internal funds. These results are relevant for electric utility firms, market operators, and policy makers, since the selective presence of derivatives markets might let financing policies globally diverge.
\end{abstract}

Keywords Corporate hedging $\cdot$ Difference-in-differences, market access $\cdot$ Market introduction · Utility industry

JEL Classification G32 $\cdot$ G38 $\cdot$ L94

\section{Introduction}

Although prominent corporate hedging theories state that hedging can be value-enhancing under certain conditions (Bessembinder 1991; Froot et al. 1993; Massa and Zhang 2018; Smith and Stulz 1985), academic literature on the determinants of corporate hedging in

Electronic supplementary material The online version of this article (https://doi.org/10.1007/s1115 6-020-00909-6) contains supplementary material, which is available to authorized users.

\section{Markus Hang}

Markus.Hang@mrm.uni-augsburg.de

Extended author information available on the last page of the article 
general suffers from its inconclusive results and a lack of comparability among the different studies (Aretz and Bartram 2010; Arnold et al. 2014; Brunzell et al. 2011; Búa et al. 2013; Carter et al. 2017; Geyer-Klingeberg et al. 2018, 2019). Especially, literature is largely silent on the determining consequences and interactions of corporate hedging activities in the presence of a multi-risk exposure, which raises the questions how hedging of one specific market risk factor affects other corporate hedging and financing decisions. This study addresses these questions by analyzing corporate hedging activities in the electric utility industry, which is rarely examined in existing literature so far (see Krajcar et al. 2008; Lievenbrück and Schmid 2014). Electric utility firms have to make large investments, trade on international markets, and rely on commodity prices, which expose them to a multi-risk exposure consisting of interest rate (IR) risk, foreign exchange rate (FX) risk, and several commodity price (CO) risks on the supply and demand side (Batra et al. 1982; Deng and Oren 2006; Lievenbrück and Schmid 2014). ${ }^{1}$

Recent introductions of electricity derivatives markets create a unique setting for the analysis of corporate hedging activities in the electric utility industry. The aim of this study is to incorporate these financial innovations as a new measure of electricity output hedging activity following the idea of Pérez-González and Yun (2013). In contrast to prior research focusing on endogenous variation in hedging behavior (i.e., hedging activities driven by internal corporate decisions), this approach uses a quasi-exogenous change in the variability of electricity derivatives (i.e., the change in hedging activity is primarily driven by external parameters). This procedure enhances the reliability of our analysis, since it contributes to the prevention of endogeneity as an econometric issue, which stems from correlation between the independent variables and the residuals of a regression model. In our case, this correlation might especially be induced by reverse causality between hedging activity and other firm characteristics included in the regression models. In this way, the aim of this study is to analyze the interactions of output hedging with a firm's other hedging activities as well as the consequences of output hedging on the sensitivities of firm values to several other risk factors. Moreover, we analyze the consequences of output hedging on a firm's financing and investment decisions as well as on its firm value. The applied difference-in-differences (DD) estimation is based on data from a sample of 159 electric utility firms that are engaged in electricity generation located in 40 different countries over the years 2005-2015.

Through this procedure, we provide two major contributions. Our first contribution is the analysis of hedging practices of electricity industries exposed to several types of risks on the input and output side, including of course commodity risks. Prior research either focuses on 'input industries', such as the airline industry (among others, Carter et al. 2006; Treanor et al. 2014) or 'output industries', such as the gold mining industry (among others, Adam 2002; Adam et al. 2015; Tufano 1996) or the oil and gas industry (among others, Bakke et al. 2016; Dionne et al. 2018; Haushalter 2000; Hong et al. 2020; Jin and Jorion 2006; Kumar and Rabinovitch 2013). As de Angelis and Ravid (2017) posit, 'however, very little work, if any, focuses on the distinction between hedging inputs and hedging outputs [...]'. In this regard, our sample of electric utilities allow the explicit distinction and simultaneous examination of hedging practices for various risks on both the input and the output side.

\footnotetext{
${ }^{1}$ On the supply (output) side, electricity is a commodity that inherits special characteristics, such as nonstorability, homogeneity, transportation restrictions, and concomitant high price volatility as well as a larger kurtosis (among others, Aïd 2015; Deng and Oren 2006).
} 
Prior literature is largely silent on hedging activities in a multi-risk exposure environment, although the single hedging strategies might have positive or negative interaction effects on each other, since, for example, spot and future returns are related between input and output commodities (Casassus et al. 2012). Indeed, electric utilities are exposed to several risks on the input and output side. Primary energy sources have to be bought to run power plants and generate electricity. In more regulated markets with monopolistic structures, fluctuating prices for primary energy sources could be passed on to the customer (natural hedge) or firms are ensured against price risks by long-term contracts and vertical integration. Since the liberalization of many electricity markets, rules of the game changed. First, organized markets are introduced to sell the produced electricity and, later, to hedge against price risks via financial derivatives. Hence, hedging against the high price volatility of electricity, which represents the major price risk on the output side (Mayer and Trück 2018), is easier and feasible for all market participants now. The importance of ensuring against electricity price risk is shown by a recent statement of the European Energy Exchange (EEX) saying that the volume of traded electricity derivatives has been grown from 85,7 TWh in December 2009 to a total of 360.3 TWh in December 2019, with futures being the dominating instrument (Hedgeweek 2020). Options and other over-the-counter contracts are rather the exception, see for example in Europe where EEX meanwhile proposes futures for 20 countries and options only for 5 countries. The availability of appropriate electricity derivatives replace prior hedging policies, such as proxy hedging (e.g., via an instrument whose underlying is highly-correlated to the electricity price) or cross hedging of electricity price risk (e.g., via a combination of a foreign electricity derivative and an appropriate currency derivative). In addition to commodity risks, electric utilities deal with many other financial risks like, for example, foreign exchange risk (due to their activities involving global commodities and their oftentimes multinational trading activities) and, thus, we are able to quantify how output hedging may modify hedging practices of those other risks. This is, to the best of our knowledge, the first empirical study analyzing electricity hedging practices.

Our second contribution is the analysis on how hedging practices are modified when straight hedging instruments become available for output hedging. Very little is known about the relation between market access and hedging, although a firm's ability to hedge crucially depends on the availability and liquidity of markets (Willems and Morbee 2010). Addressing the impact of market access on risk mitigation, Bartram (2019) finds that in countries with easier access to derivatives markets, derivatives users achieve greater reduction in stock return volatility. Empirically investigating firm value, Pérez-González and Yun (2013) employ the natural event of the introduction of weather derivatives and detect an increase in firm value of weather sensitive firms after the introduction of the market. By analyzing the introduction of electricity derivatives markets as a quasi-natural change in market access for output hedging and the related consequences on hedging practices for multiple other risk factors, this study contributes to this strand of research.

The remainder of this study is structured as follows. Section 2 reviews theoretical literature in order to derive the research hypotheses for the focal relations. The dataset is presented in Sect. 3. Section 4 describes the DD estimation. The results are presented in Sect. 5. Section 6 finally concludes. 


\section{The role of electricity derivatives markets}

The theoretical foundation of the impact of electricity output hedging measured by electricity derivatives market introductions on other hedging activities, risk exposure, financing decision, investment decision, and firm value are outlined in this section. Based on those theoretical elements, six hypotheses are formulated and tested in the empirical section.

\subsection{Hedging behavior}

First, the introduction of new domestic electricity derivatives markets increases the availability of hedging instruments (often limited to simple future products) and improves access to financial derivatives for domestic companies. When no domestic electricity derivatives markets are available, electric utilities can rely either on proxy hedging using a highly correlated instrument or cross-hedging using two alternative instruments with an auxiliary underlying to replace the missing contract (see Ghosh 1996). The domestic electricity derivatives markets may often be the preferred solution for hedging. Indeed, since non-storability and limited transportation of electricity lead to price divergences among different national electricity markets, domestic electricity derivatives markets are usually accompanied by higher correlations between domestic electricity prices and derivatives' underlying prices (see also Haushalter 2000). Furthermore, especially smaller firms that fear costs involved with hedging could prefer domestic market places to buy electricity derivatives following the economies of scale theory (Nance et al. 1993). Since linguistic and legal constraints are reduced, firms could hedge their electricity price risk exposure via domestic derivatives markets at lower costs compared to foreign electricity derivatives or commodities derivatives. We therefore postulate the first following hypothesis:

H1 The introduction of electricity derivatives markets affects a firm's decision to hedge.

The introduction of electricity derivatives markets fosters the availability of hedging instruments, market liquidity, and the number of market participants, which should drive a firm's hedging volumes in addition to the decision to hedge at all, as stated in $H 1$ (Willems and Morbee 2010). Indeed, the introduction of a domestic electricity markets may push a company to start hedging activities. Moreover, if a firm employs a proxy-hedge (for example, via oil, gas, or coal derivatives) the overall hedging volumes of the related hedging positions increase after the introduction of a domestic electricity derivatives market. This is the case if, for example, the operator of a fossil fuel power station at first hedges the open balance between the coal input price risk and the electricity output price risk only via coal derivatives. This consists in hedging the existing spread, comparable to the crack spread (Alexander et al. 2013; Dempster et al. 2008; Murat and Tokat 2009) or the spark spread (Deng et al. 2001; Deng and Oren 2006; Li and Kleindorfer 2009) which makes the firm able to ensure economic profits. But the availability of appropriate electricity derivatives then enables to hedge input and output risks separately and mechanically increases the total general hedging volumes. In addition, electricity output hedging might have direct consequences on commodity input hedging strategies, since the involved commodity spot and future prices are connected (Casassus et al. 2012). This also holds for foreign exchange risk hedging, because the increased volume of commodity hedging derivatives is often combined with foreign exchange derivatives since commodity markets are often not quoted in 
the domestic currency. In contrast, electric utility firms usually have a very good vision of their output risks and better forecast its output prices than other market factors. This in turn might encourage a firm to focus on output hedging and to allow more risk on the other risk factors. This could lead to reduced hedging practices for other risk factors than electricity price risk. Another reason why the introduction of electricity derivative market may change an electric utility's hedging volumes is that electricity future prices are contango markets in the short term and backwardation markets in the long term (Bierbrauer et al. 2007; Geman 2009), electric utility firms can profit from future trading in the short term by ensuring higher selling prices and therefore increase the volume of derivatives they are dealing with.

H2 The introduction of electricity derivatives markets affects a firm's hedging volumes.

\subsection{Risk exposure}

In general, corporate hedging is a strategy to reduce uncertainty concerning future payment obligations and thereby risk mitigation (Deng and Oren 2006; Stulz 2004). In this sense, the introduction of electricity derivatives markets enhances market completeness and improves the allocation of risks (Willems and Morbee 2010). Hence, hedgers might achieve lower earnings volatility in countries where access to derivatives markets is easier. Additionally, domestic electricity derivatives markets offer a higher correlation between domestic electricity prices and the derivatives' underlying price, as outlined above. Consequently, the risk exposure is generally expected to decrease after the introduction of electricity derivatives markets for the related firms. This also particularly holds for market risk, since electricity prices are linked to a country's economic situation (Arora and Lieskovsky 2014; Jamil and Ahmad 2010). Hence, lower electricity risk reduces a firm's overall market risk. Moreover, a negative spillover effect is also supposed for FX risk, since electricity hedging ensures the basis for evaluation and predictability of the firm outputs. This also encourages a firm to hedge and, thus, lower its FX risk associated with its inputs and outputs. The same argument might also hold for IR risk. However, also a positive effect could be expected for FX and IR risks, since investment volumes as well as the levels of debt financing might increase with more stable earnings (Graham and Rogers 2002; Leland 1998; Myers 1977). For commodity input risks, either a positive or a negative effect could be assumed depending on the hedging practices before the electricity derivatives market introduction. Accordingly, the commodity input risks could decrease, since commodity risks now can be hedged more precisely and, consequently, to a greater level. On the other side, a firm might want to keep the same risk level. Thus, since a firm can reduce efficiently the output risk, it may want to increase in parallel the input risk. However, if a firm employed a proxy-hedge (for example via gas derivatives), the associated commodity risk raises due to the mechanically decreasing hedging volumes when electricity risks are hedged with electricity derivatives.

H3 The introduction of electricity derivative markets affects a firm's risk exposure.

\subsection{Financing and investment}

As proposed by several authors, firms might jointly make decisions concerning corporate hedging, financing, and investment (among others, Froot et al. 1993; Hahnenstein 
and Röder 2007; Lin et al. 2008; Ross 1977). In this context, multiple studies argue that corporate hedging activities have a positive influence on leverage (Graham and Rogers 2002; Leland 1998; Lin et al. 2008; Stulz 1996). By reducing earnings volatility, hedging increases debt capacities with regard to the realization of tax benefits from higher interest deductions (Leland 1998). In contrast, Jensen and Meckling (1976) propose that corporate hedging has a negative effect on leverage ratio. Accordingly, a smaller amount of hedging activities creates value in terms of high levels of external financing-dependent on a high probability of upper tail outcomes. Since the introduction of electricity derivatives markets is assumed to potentially increase or decrease the hedging volumes of electricity hedgers, the following hypothesis is proposed:

H4 The introduction of electricity derivative markets affects a firm's level of debt financing.

Furthermore, Bessembinder (1991) argues that hedging transfers a larger proportion of incremental returns on investment to shareholders and fixes future cash flows. According to Froot et al. (1993), hedging might also avoid costly external financing. Consequently, when external capital is more costly than internal funds, hedging activities contribute to the availability of internal funds by lowering earnings volatility in order to benefit from additionally profitable investment opportunities. Since hedging reduces potential underinvestment problems (Myers 1977), the introduction of electricity derivatives markets is expected to have a positive impact on investments of electricity hedging firms. Since domestic electricity derivatives markets provide better risk mitigation properties and/or enable a firm to reach a certain risk position at lower costs, the introduction of electricity derivatives markets is assumed to reinforce this effect.

H5 The introduction of electricity derivatives markets affects a firm's investment volumes.

\subsection{Firm value}

Positive theory of corporate hedging states that hedging can be value enhancing with regard to market frictions, such as corporate taxes, bankruptcy costs, asymmetric information, or agency conflicts (Bessembinder 1991; Froot et al. 1993; Smith and Stulz 1985). In contrast, firm values should be independent from hedging activities following the managerial utility maximization theory (Jin and Jorion 2006). Hence, risk-averse managers are assumed to prefer hedging, if their personal wealth depends on the firm value, and hedging on the firm level is less costly than on a personal level (Smith and Stulz 1985). Moreover, managers usually claim extra compensation for non-diversifiable risks. If the costs of hedging are smaller than the reduction in extra compensation, firm value increases (Smith and Stulz 1985).

In their seminal article, Allayannis and Weston (2001) hypothesize for the first time that corporate hedging activities might also have a direct impact on firm value. Lookman (2004), DeMarzo and Duffie (1995) and Tufano (1996) propose that corporate hedging itself might be a signal of good managerial quality. Furthermore, corporate hedging might lead to significant cash flow gains (for example, due to positive developments of the spot price over the contracted forward price), which directly add value to the firm independent from firm risk (Adam and Fernando 2006). If better market access promotes hedging, and hedging increases firm value, it is expected that the introduction of new electricity derivatives markets increases firm values in affected countries. 
Alternatively, de Angelis and Ravid (2017) argue that commodity output hedging, as in the case of electricity hedging, might result in adverse effects for electricity utility firms. Accordingly, output hedging destroys investors' "sector play", since the desired industry risk is hedged. Furthermore, output hedging encourages over-production and distorted prices. These implicit costs of hedging are even more pronounced for firms with high market power (de Angelis and Ravid 2017), as is typically the case in the utility industry. Furthermore, Phan et al. (2014) document a negative effect of commodity output hedging for US oil and gas companies, while this effect depends on oil and gas price movements. Negative effects particularly arise in times of increasing prices, while positive effects exists when prices decline.

H6 The introduction of electricity derivative markets affects a firm's market value.

\section{Dataset}

The global sample of electric utility firms is based on the MSCI World Utility Index and the World Utility Index from Thomson Reuters. We focus on listed firms because reliable data for unlisted firms are mostly unavailable. After the elimination of duplicates, the sample is reduced to firms assigned to the SIC codes 4911 (Electric Utilities) and 4931 (Electricity and Other Services Combined) in order to exclude firms not engaged in electricity generation. All data are collected for the period between 2005 and 2015 due to the better availability of hedging data since 2005 motivated by the introduction of the International Accounting Standard 39 (IAS 39) in 2001 and its stepwise amendment. Furthermore, relevant commodity prices (oil, gas, coal, electricity) did not evolve in just one direction in this period. Consequently, our results are valid for increasing as well as decreasing market environments. As summed up in Online Appendix A, the following variables are used in the analyses in this work.

\subsection{Hedging information}

Hedging information for the data set is collected by manually screening the annual reports. The documents are derived from company websites, Morningstar Quicktake and the EDGAR company search from the US Security Exchange Commission. A keyword search is conducted following existing articles by, among others, Bartram et al. (2009) and Lievenbrück and Schmid (2014). The following keywords are used to identify text passages possibly containing hedging information: "Hedg", "Risk Manag", "Market Risk", "Commodit", "derivative", "financial instrument", "notional", "nominal", "contractual volume", "contracted volume", "principal".

Based on the identified hedging content, a hedging dummy variable is constructed first, which indicates whether a firm uses financial derivatives in the corresponding year to hedge a certain risk type. Otherwise, the firm is classified as a non-hedger in the corresponding year. We refer to these dummy variables by GH. $D_{i, t}$ (total general hedging), $I R$. $D_{i, t}$ (interest rate hedging), $F X . D_{i, t}$ (foreign exchange rate hedging), CO.D $D_{i, t}$ (commodity price hedging) and EL. $D_{i, t}$ (electricity price hedging). Second, the notional values of the hedging extent are used to construct the related continuous hedging variables. Following existing works (among others, Campello et al. 2011; Graham and Rogers 2002; Lievenbrück and Schmid 2014), notional values serve as a better measure for the amount secured 
Table 1 Overview of electricity derivatives markets

\begin{tabular}{llll}
\hline Year & Name & Abbreviation & Countries \\
\hline 1980 & ICE Futures Europe & ICE & UK \\
1993 & NordPool ASA & NPX & Norway \\
2001 & Korea Power Exchange & KPX & South Korea \\
2001 & Powernext & PNX & France \\
2002 & Australian Stock Exchange & ASX & Australia, New Zealand \\
2002 & European Energy Exchange & EEX & Austria, Germany \\
2003 & Natural Gas Exchange & NGX & Canada \\
2003 & Japan Electric Power Exchange & JEPX & Japan \\
2005 & Moscow Energy Exchange & MEX & Russia \\
2006 & Iberian Electricity Market & MIBEL & Portugal, Spain \\
2007 & Power Exchange Central Europe & PXE & Czech Republic \\
2008 & Polish Power Exchange & POLPX & Poland \\
2008 & Italian Derivatives Energy Exchange & IDEX & Italy \\
2009 & Nodal Exchange & NODAL & US \\
2010 & Hungarian Power Exchange & HUPX & Hungary \\
2013 & European Energy Exchange & EEX & Belgium, Greece, Switzerland \\
2016 & Independent Bulgarian Energy Exchange & IBEX & Bulgaria \\
\hline
\end{tabular}

This table presents information on the electricity derivatives markets analyzed in this study. Beside the year of introduction, the name, the abbreviation and the countries are given, for which electricity derivatives are offered by the respective exchange

in contrast to fair values. Following Lievenbrück and Schmid (2014), the variables are scaled by a firm's total assets and set to one if the hedging volume exceeds the sum of the balance sheet. The continuous variables are denoted as GH. $V_{i, t}, I R . V_{i, t}, F X . V_{i, t}, C O . V_{i, t}$, and $E L . V_{i, t}$. A detailed description of the search procedure is available in Online Appendix B. Overall, data is available for 159 companies (1749 firm year-observations) from 40 countries. An overview of the geographical distribution of the data and the hedging behavior can be found in Online Appendix C and Online Appendix D.

In addition, a dummy variable for extensive EL hedging $\left(E x t_{i, t}\right)$ is constructed, indicating if $E L . V_{i, t}$ is above the $75 \%$ quantile of all reported notional values for EL hedging. Analogously, a dummy variable for sparse EL price hedging $\left(\operatorname{Spar}_{i, t}\right)$ takes on the value of one, if the reported volume is below the $75 \%$ quantile. Firms that are not engaged in EL hedging serve as the reference category.

\subsection{Market introductions}

To identify relevant electricity derivatives markets, we conduct an extensive research using online resources. For each country, for which corporate hedging information is available, we are interested in the date of the initial introduction of an electricity derivatives market. If a country experienced more than one electricity derivatives market introduction, we prefer the event that falls into the observation period. Since each market introduction leads to a higher availability and liquidity of electricity derivatives, this procedure increases the number of events, while avoiding an overestimation of the effects of interest. Table 1 sums up the identified electricity derivatives markets analyzed in this study. 
Based on this information, several variables are constructed, which are necessary for the application of a difference-in-differences estimator (Angrist and Krueger 1999; Bakke et al. 2016; Gilje and Taillard 2017; Pérez-González and Yun 2013). A treatment dummy variable $\left(T_{i}\right)$ is defined to indicate if a firm is located in a country, where one of the 16 electricity derivatives markets exists. Therefore, each firm is assigned to the country, where its headquarters is located. In addition, $m$ event dummy variables $\left(E_{t}^{m}\right)$ are constructed, which take on the value of zero before and the value of one after an electricity derivatives market is introduced. Hence, these variables cover time fixed effects such as systematic variation in variables of interest affecting the whole industry. As seven events fall into the observation period and two of them happen in the same year, six event variables are included in the analyses $(m=6)$. Finally, the interaction term of interest $\left(E_{t} x T_{i}\right)$ is constructed, which takes on the value of one after an electricity derivatives market is introduced in a certain country. Hence, this moderating effect measures the impact of electricity derivatives market introductions. For observations from countries, in which an electricity derivatives market was introduced before the start of the observation period in 2005 (no event dummy variable included), the interaction term always takes on the value of one. In the same way, the interaction term takes on the value of zero if the electricity derivatives market was introduced after 2015.

\subsection{Risk Exposure}

As an additional aim of this study, the effect of electricity derivatives market introductions on a firm's risk exposure is investigated. The risk exposure is estimated by a multifactor model following the idea of the standard Capital Asset Pricing Model in order to derive the sensitivity of a firm's stock return on diverse risk factors. Therefore, we build on the works by Bartram (2019) and Choi et al. (1992), but extend it by differentiating between the various relevant commodity prices that are particularly relevant for electric utility firms. The magnitude of each risk exposure is estimated on daily data. As a consequence, we estimate a time series of yearly beta factors for each firm and for each risk exposure across the observation period. In order to estimate the risk exposure for each firm in each year, we estimate the respective beta coefficients by the following linear model using daily data:

$$
R_{t}=\alpha+\beta^{M} R_{t}^{M}+\beta^{I R} R_{t}^{I R}+\beta^{F X} R_{t}^{F X}+\beta^{\text {Oil }} R_{t}^{\text {Oil }}+\beta^{\text {Gas }} R_{t}^{\text {Gas }}+\beta^{\text {Coal }} R_{t}^{\text {Coal }}+u_{t},
$$

where $R_{t}$ is the firm's stock return of the day $t, \alpha$ is the intercept, $R_{t}^{M}$ is the return of a firm's national non-financial market index, $R_{t}^{I R}$ is the change-rate of the inter-bank offered rate of the respective market, $R_{t}^{F X}$ is the percentage change of an exchange rate index of the respective currency, $R_{t}^{\text {Oil }}, R_{t}^{\text {Gas }}$, and $R_{t}^{\text {Coal }}$ are the returns of historical settlement prices of futures in the region the firm is located in for oil, gas, and coal, and $u_{t}$ is the idiosyncratic risk with mean zero. ${ }^{2}$ To eliminate outliers, all risks factors measured by the regression coefficients in Eq. (1) are winsorized at the $1 \%$ and $99 \%$ quantile.

\footnotetext{
${ }^{2}$ Three-month interbank or deposit middle rates are received from Datastream. Trade-weighted currency indices published by the Bank of England (BOE) and foreign exchange spot rates from Morgan Stanley Capital International (MSCI) are used.
} 


\subsection{Firm characteristics}

Moreover, we include several firm characteristics in the analysis following related articles. $^{3}$ In the subsequent analyses, financing behavior is measured by leverage ratio (total debt divided by common equity) and investment decisions are proxied by capital expenditure (capital expenditure divided by total assets). Additionally, we use Tobin's Q (ratio of total assets minus book value of common equity plus the market value of common equity to total assets) as a proxy variable for firm value. In addition, the following variables are selected as control variables: interest coverage ratio (EBIT divided by interest expenses on debt), liquidity (quick ratio), dividend yield (dividend divided by share price), profitability (return divided by total assets), firm size (logarithm of total assets), and tax loss carry-forwards (maximum of operating expenses minus revenue and zero divided by total assets). If leverage ratio, capital expenditures, and Tobin's Q are not used as dependent variable, they are also integrated in the analyses as control variables. All control variables are received from Datastream and winsorized at the $1 \%$ and $99 \%$ quantile.

\section{Difference-in-differences estimation}

The aim of this study is to investigate the access to financial derivatives in the form of the introduction of electricity derivatives market as exogenous events. Following Angrist and Krueger (1999), Bakke et al. (2016), Gilje and Taillard (2017), Meyer (1995) and PérezGonzález and Yun (2013), we apply DD estimation, which is well-suited for the analysis of such quasi-natural experiments. In this way, firms treated by electricity derivatives market introductions are compared to a control group of non-treated firms, before and after the event of a market introduction respectively. In general, the DD regression is as follows:

$$
y_{i, t}=\alpha+\delta T_{i}+\sum_{m=1}^{M} \gamma^{m} E_{t}^{m}+\rho\left(E_{t} x T_{i}\right)+\sum_{k=1}^{K} \beta^{k} X_{i, t}^{k}+\varepsilon_{i, t},
$$

where the dependent variable $y_{i, t}$ is regressed on a treatment variable $T_{i}$ that equals one if a firm belongs to the treatment group (countries where a electricity derivatives market exists), a set of $m$ event variables $E_{t}^{m}$ that equal one after a certain event $m$ (time fixed effects), the interaction term $\left(E_{t} x T_{i}\right)$ that equals one if a firm is affected by an event, after the event occurred, and a set of $k$ control variables $X_{i, t}^{k}$. The regression coefficient $\rho$ is the DD estimate of interest, $\varepsilon_{i, t}$ is the error term. Analogous to testing moderating effects in standard regression analysis, all variables included in the interaction term are also included in the regression equation one by one, which ensures that the moderating effect is isolated properly. Considering the panel structure of the data, we follow the proceeding of Bakke et al. (2016), Gilje and Taillard (2017), and Pérez-González and Yun (2013) and use clustered standard errors on the firm level in all calculations. ${ }^{4}$

\footnotetext{
3 To identify common determinants, especially the studies of Bartram et al. (2009), Dionne et al. (2018), Graham and Rogers (2002), Haushalter (2000), Kumar and Rabinovitch (2013), Mian (1996), Mnasri et al. (2017), Pincus and Rajgopal (2002), and Wang and Fan (2011) were consulted.

${ }^{4}$ Clustered standard errors are preferred against fixed-effects estimation, since the fixed effects would fully absorb the effects of interest included in the DD estimator. In order to justify the waiver of a random-effects model, the Hausman test for endogeneity (Hausman 1978) is employed to the different regression analyses including solely the control variables as explanatory variables. The statistically significant test results con-
} 
In order to test the various research hypotheses of this study, Eq. (2) is applied with several adjustments as displayed in Table 2. In order to test H1, Eq. (2) is applied by a probit regression, which is estimated via maximum likelihood estimation analyzing each hedging dummy variable $\left(G H . D_{i, t}, I R . D_{i, t}, F X . D_{i, t}, C O . D_{i, t}\right.$, and EL.D $\left.D_{i, t}\right)$ as dependent variable. For interpretation, the results are presented as marginal effects.

For $H 2$, the dependent variable $y_{i, t}$ is represented by the hedging volume variables $(G H$. $V_{i, t}, I R . V_{i, t}, F X . V_{i, t}, C O . V_{i, t}$, and EL. $\left.V_{i, t}\right)$ in a panel data analysis. In addition, the dummy variables representing extensive and sparse EL hedging $\left(E_{i, t}\right.$ and $\left.\operatorname{Spar}_{i, t}\right)$ are multiplied with the interaction term $\left(E_{t} x T_{i}\right)$. Hence, the DD estimate is further partitioned into two effects allowing to distinguish between the effect on firms that extensively engage in EL hedging, sparsely respectively. The related triple differences (DDD) are denoted by $E_{t} x T_{i} x E x t_{i, t}$ and $E_{t} x T_{i} x \operatorname{Spar}_{i, t}$. Following again the standard procedure when testing moderating effects in regression analysis, besides the triple differences, all pairwise combinations of the related variables have to be included in the regression equation as well as all variables one by one. This procedure ensures that the variables of interest (DDD) measure the properly isolated effect. The same adjustments are made to examine $H 3$ and $H 4$, using the risk factors $\left(\beta_{\mathrm{i}, \mathrm{t}}^{\mathrm{M}}, \beta_{\mathrm{i}, \mathrm{t}}^{\mathrm{IR}}, \beta_{\mathrm{i}, \mathrm{t}}^{\mathrm{FX}} \beta_{\mathrm{i}, \mathrm{t}}^{\mathrm{Oil}}, \beta_{\mathrm{i}, \mathrm{t}}^{\mathrm{Gas}}\right.$, and $\left.\beta_{\mathrm{i}, \mathrm{t}}^{\mathrm{Coal}}\right)$, financing (leverage ratio), investment (capital expenditures), and firm value (Tobin's $Q$ ) as dependent variables.

\section{Results}

In this chapter, the data sample is described at first followed by univariate analyses of the control variables. In the center of this section, the introductions of electricity derivatives markets are analyzed via DD estimation. Here, we especially investigate the implications for corporate hedging activities, risk exposure, and firm value.

\subsection{Descriptive statistics}

Figure 1 shows the geographical distribution of the data set, which covers a total of 40 countries distributed among five continents. The differing blue shades classify the average hedging intensity $\left(G H . V_{i, t}\right)$ of firms located in the respective country. According to this illustration, corporate hedging is most pronounced in North America, Europe, Australia and New Zealand. An orange dot marks countries where an electricity derivatives market exists. Obviously, hedging practices are overall heterogeneous across the different countries in the dataset. However, electricity derivatives market are especially present in developed countries.

The development of hedging decisions and hedging volumes across the observation period is shown in Fig. 2. The first observation is that hedging in general has continuously increased over the analyzed period. But this strong trend seems to change recently: the decision to hedge IR and FX risks decreases in recent year. Also, the hedging volumes

Footnote 4 (continued)

firm the general appropriateness of a fixed-effects model, except for three individual models. For the sake of consistency, fixed effects are assumed in all regression models as represented by the included DD estimators. 


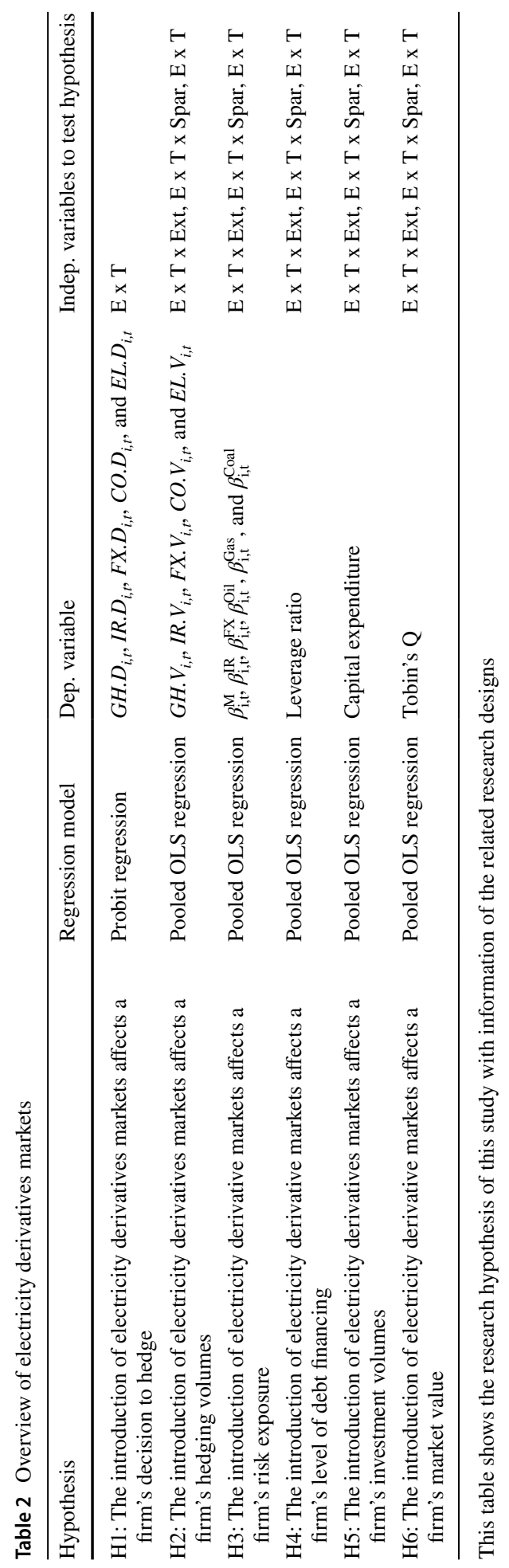




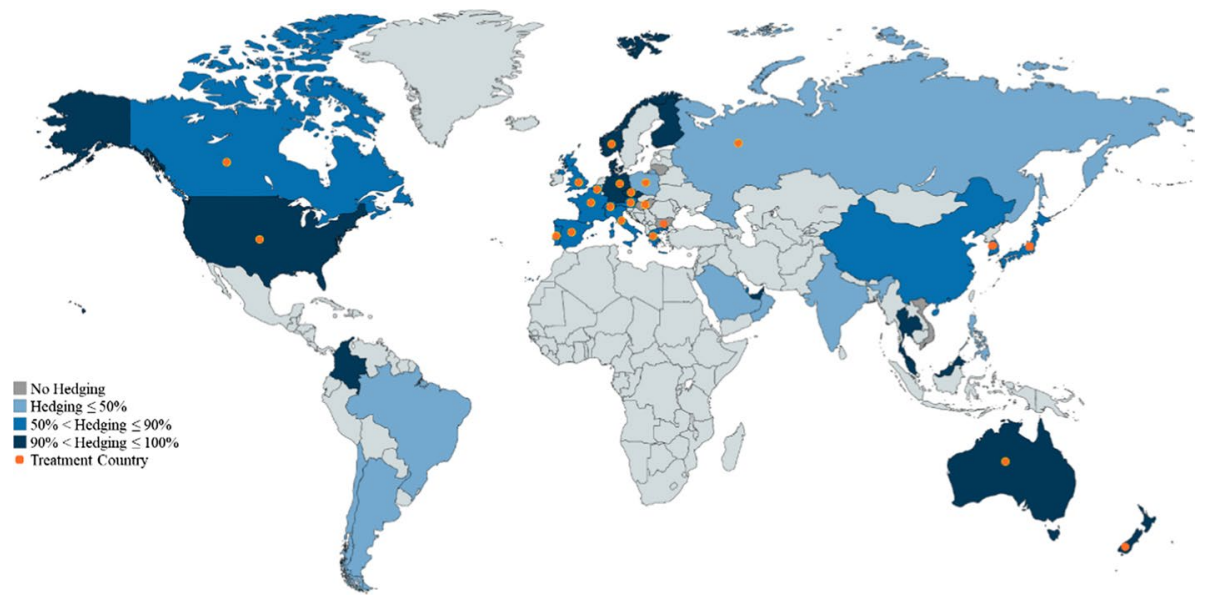

Fig. 1 Geographical overview

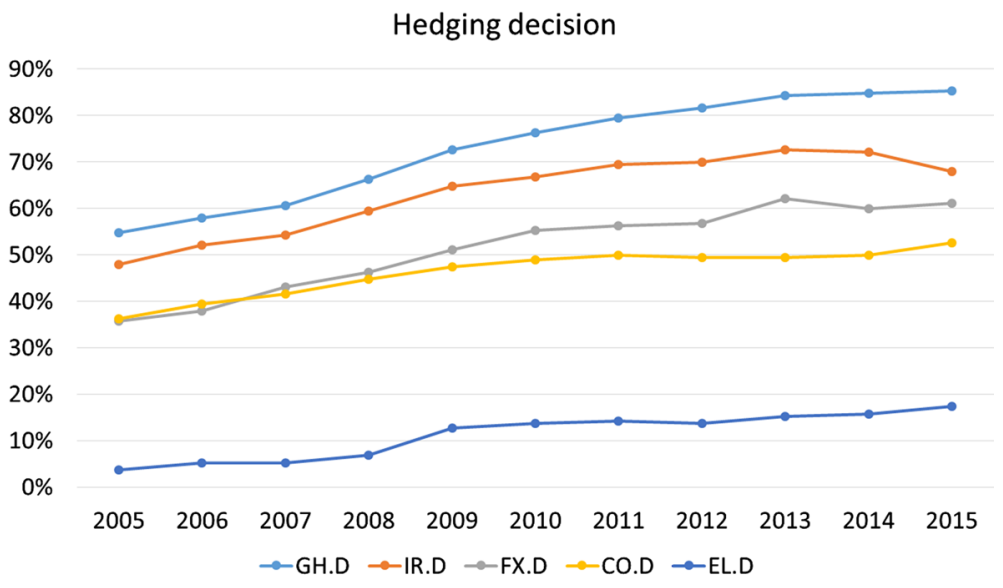

\section{Hedging volume}

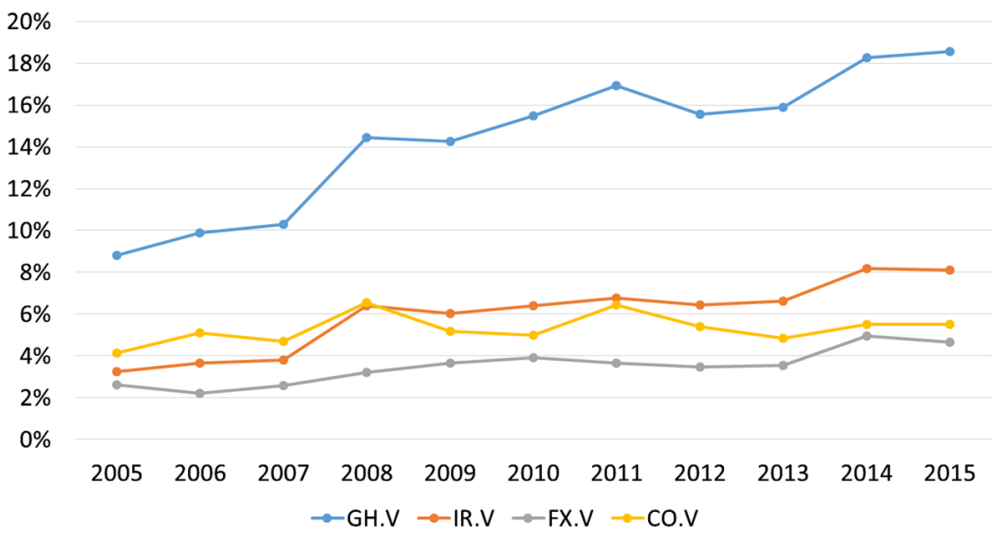

Fig. 2 Hedging information 
of IR, FX, and CO risks is declining. In contrast, the decision to hedge electricity risk is monotonously increasing as well as the hedging activities in general.

The sample includes $75 \%$ hedging firms, which seem to strongly differ from the remaining $25 \%$ non-hedging firms, as the descriptive statistics of the control variables show in Table 3. According to the mean difference test between hedgers and non-hedgers, hedging firms are expected to have a higher leverage ratio $(t$-value $=4.77)$, a lower liquidity $(t$-value $=-4.20)$, a lower profitability $(t$-value $=-3.39)$, and a larger firm size $(t$-value $=17.92)$ as compared to non-hedgers. The significant differences in tax loss carryforwards ( $t$-value $=-3.64)$ and capital expenditure $(t$-value $=-5.88)$ can be seen as economically marginal due to small values. This univariate analysis should solely provide first indications, keeping in mind a potential overestimation compared to multivariate methods and the potential presence of spurious effects. The correlation matrix for the analyzed firm characteristics is presented in Online Appendix E.

Moreover, Fig. 3 shows the average firm risk betas estimated by Eq. 1 around the introduction of electricity derivatives markets. As the plot demonstrates, foreign exchange rate risk as well as the overall market risk reveal the greatest (absolute) beta coefficient. Obviously, the market risk exposure decreases while the FX exposure increases in absolute terms at the introduction of electricity derivatives markets in $t=0$. This can be seen as an indicator that the products offered by new electricity derivatives markets enable utility firms to improve (reduce) their overall risk exposure while interaction effects with other risk factors are observable especially for FX risk.

\subsection{Hedging behavior}

Starting with the analysis of the effect of electricity derivatives market introductions on the decision to hedge at all, the results of the DD probit regressions are presented in Table 4.

The DD estimate of interest ( $E x T$ ), reveals two statistically significant results. First, the introduction of electricity derivatives markets is found to clearly offer an incentive to a firm to start hedging electricity (output) price risk in a treated country $\left(\beta_{E L . D}^{E x T}=0.218\right)$. Hence, the availability of domestic electricity derivatives motivates a firm to start hedging its output risk. ${ }^{5}$ Second, if a firm is located in a treated country, the introduction of the electricity derivatives market in this country leads to an increase in the number of firms deciding start hedging FX risk $\left(\beta_{F X . D}^{E x T}=0.347\right)$. Consequently, there are significant interactions between hedging activities as the availability of electricity derivatives also motivates a firm to hedge FX risk. However, these results should be considered cautiously, since hedging measured by a dummy variable only refers to the decision to start hedging at all, which represents a

\footnotetext{
5 In a robustness test we investigate, if national electricity derivatives markets are potentially introduced due to increased electricity hedging demand (e.g., on foreign markets) before the actual national introduction, speaking for a reverse causality and, thus, against the quasi-exogeneity condition. However, the analysis of the impact of prior electricity hedging decisions (two-year and three-year lag) on the later introduction of electricity derivatives markets reveals no significant results. So there was no increase in electricity hedging demand right before the national market introduction. Additionally, we perform a robustness test where we analyze if an increase in hedging demand is observable for firms when an electricity derivatives market is created in a neighbouring country or in a country connected via undersea cable before the creation of the national market (Polish firms-PXE, Hungarian firms-PXE, Greek firms-IDEX, Swiss firmsIDEX). The results show that there is no significant increase in hedging demand. For this reason, we assume that the creation of national electricity derivatives markets is not driven by hedging demand and we conclude quasi-exogeneity for our analysis. The statistical results are available on request.
} 


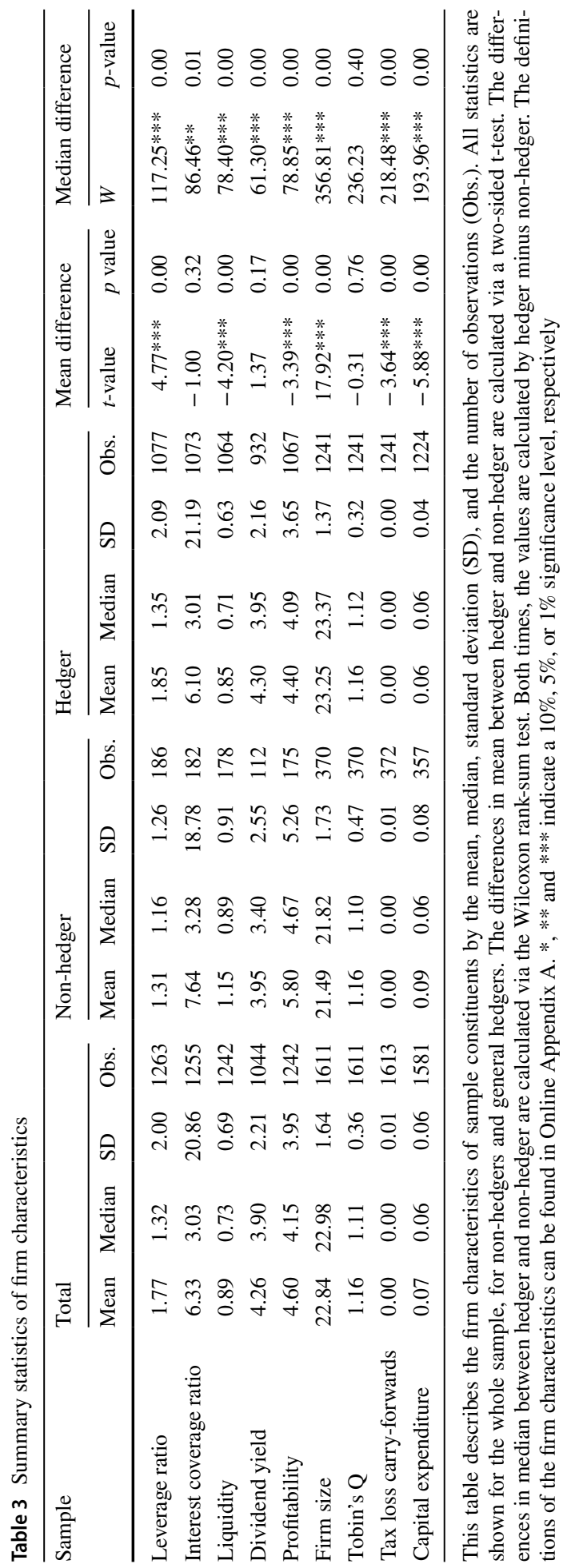




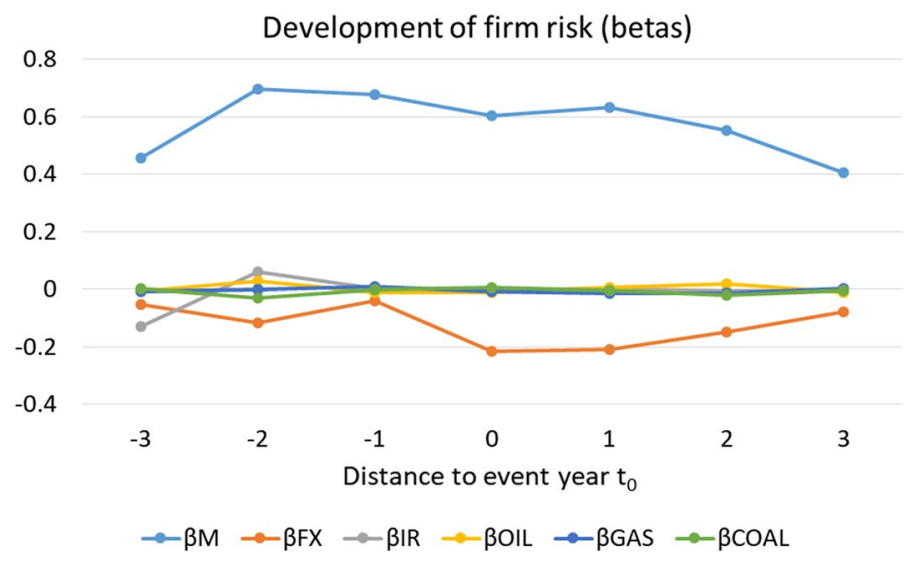

Fig. 3 Development of firm risk

different meaning than the absolute hedging intensity. Hence, the dummy variables also suffer from a remarkable loss of information compared to the continuous equivalents, since it only differentiates between hedging and non-hedging and does not consider the absolute intensity of hedging. Among the further determinants of corporate hedging, leverage, interest coverage, and firm size seem to be the main influential factors for hedging decisions in the utility industry. These results are in line with prior influential studies (among others, Allayannis and Weston 2001; Choi et al. 2015).

In the following, the results for the corresponding hedging volumes presented in Table 5 are described. Therein, the two additional variables Ext and Spar make it possible to investigate differences in the effect of electricity derivatives market introductions between extensive and sparse EL hedgers. Consequently, two further DDD estimates ( $E x \quad T \times E x t$ and $E x T \times$ Spar) are included in the analyses. Since the introduction of a derivatives market cannot be equated with the use of derivatives offered by this market (in comparison, for example, firms automatically have to abide by the new law, when it is passed), the two DDD estimates are necessary in our case. In order to calculate the total effect, for example, for extensive electricity hedgers, the corresponding DDD estimate has to be added to the DD estimate. The results show significant interactions between electricity output hedging and the other hedging activities of a firm, but the effects differ between extensive and sparse EL hedgers. Thus, increasing volumes of EL hedging are in general correlated with total general hedging volumes, commodity hedging volume, IR hedging volumes, and FX hedging volumes of a firm.

In terms of total general hedging, an adverse effect is observable for extensive EL hedgers $\left(\beta_{G H . V}^{E x T x E x t}=-0.190\right)$. This illustrates that the existence of a domestic electricity derivatives market might coincide with better risk mitigation properties and enables a firm to reduce their earnings volatility with lower derivatives volumes (Bartram 2019). Due to their precise domestic market knowledge, electric utility firms are able to predict their output prices that have a major impact on firm outcomes more precisely than its other risk factors due to the firms' pricing power. Accordingly, the availability of domestic electricity derivatives that are highly correlated with the underlying domestic electricity price especially contributes to a reduction of earnings volatility. Furthermore, the DDD estimates for IR hedging $\left(\beta_{I R . V}^{\text {ExTxSpar }}=-0.159, \beta_{I R . V}^{\text {ExTExt }}=-0.158\right)$ show that EL hedging 


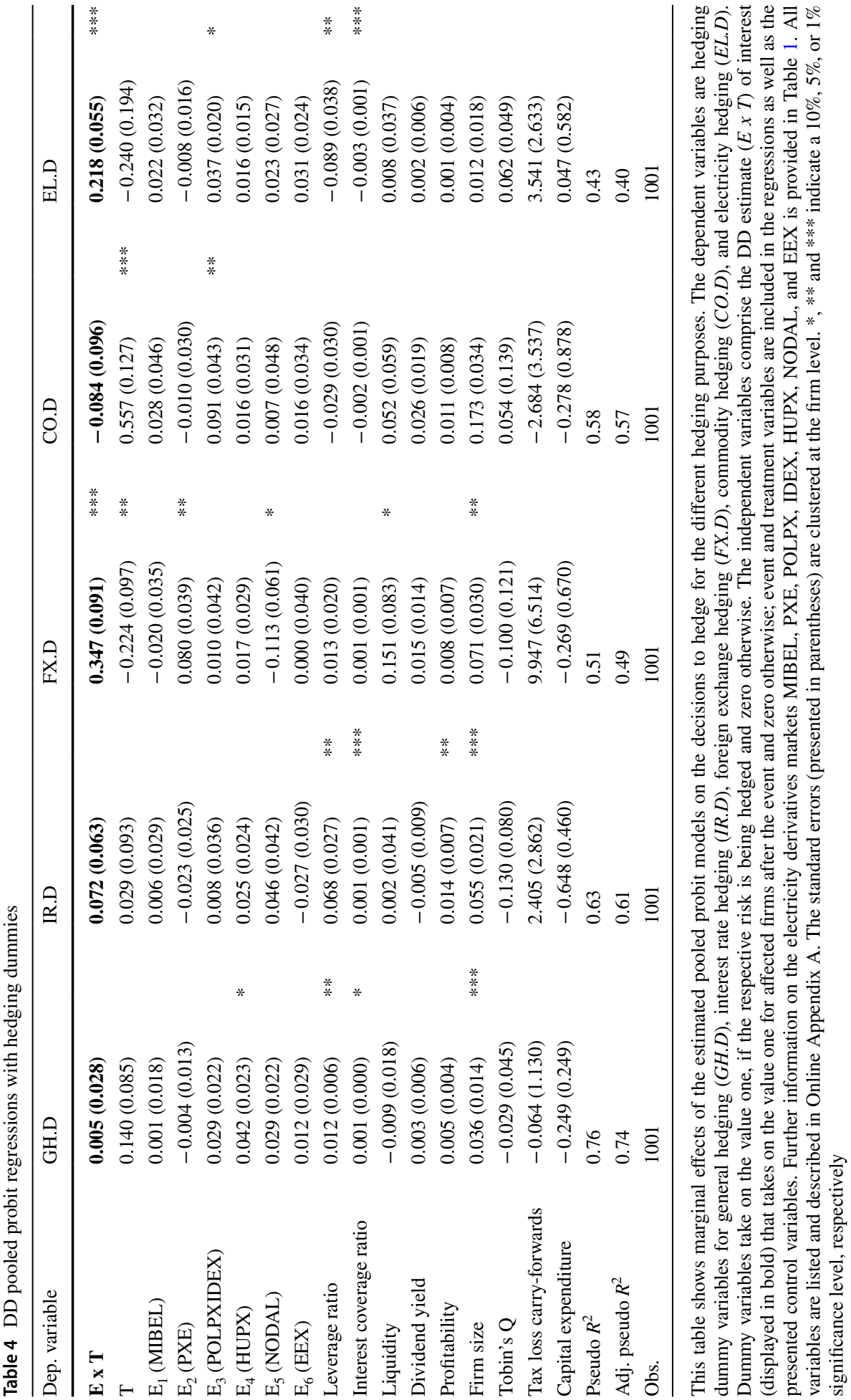




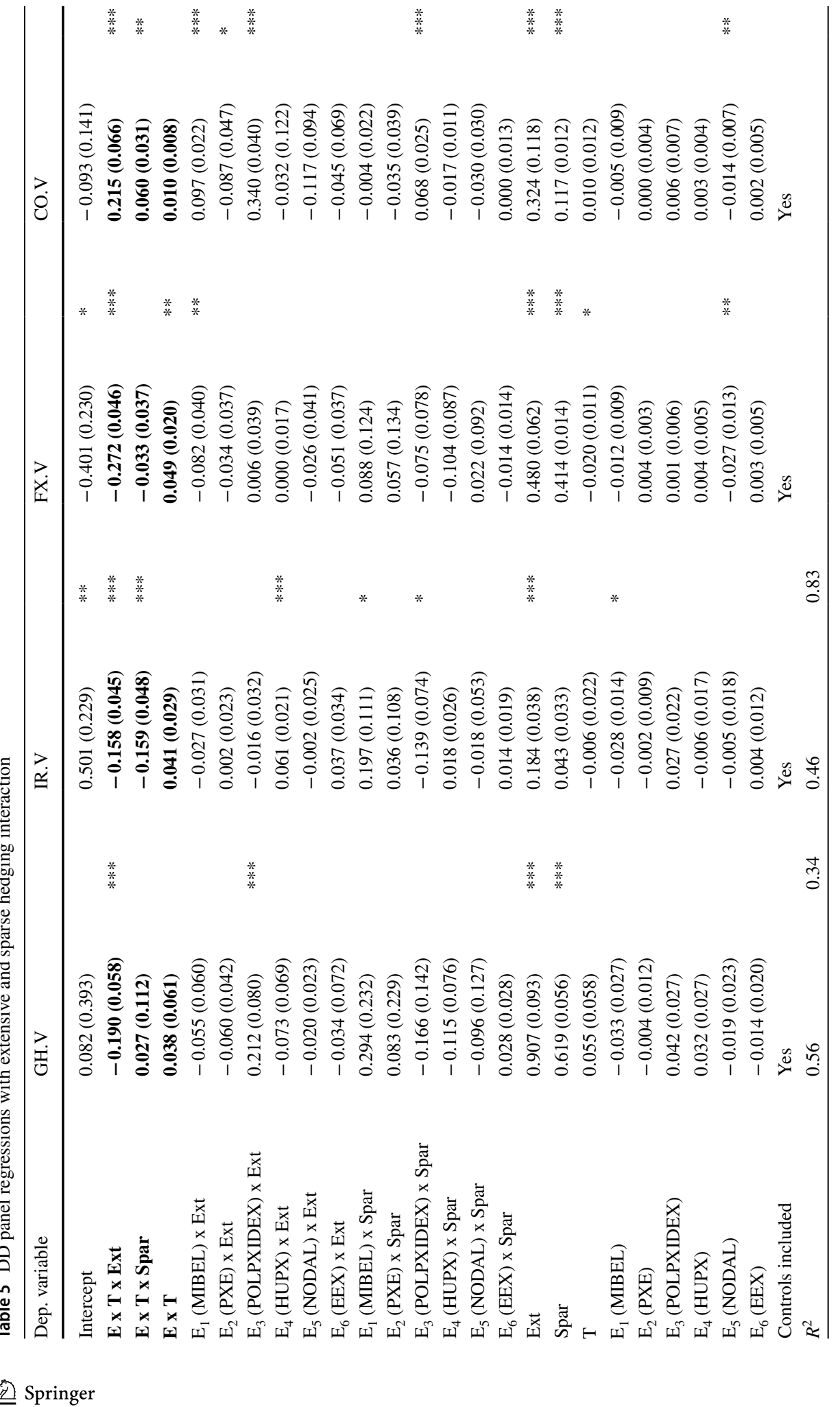




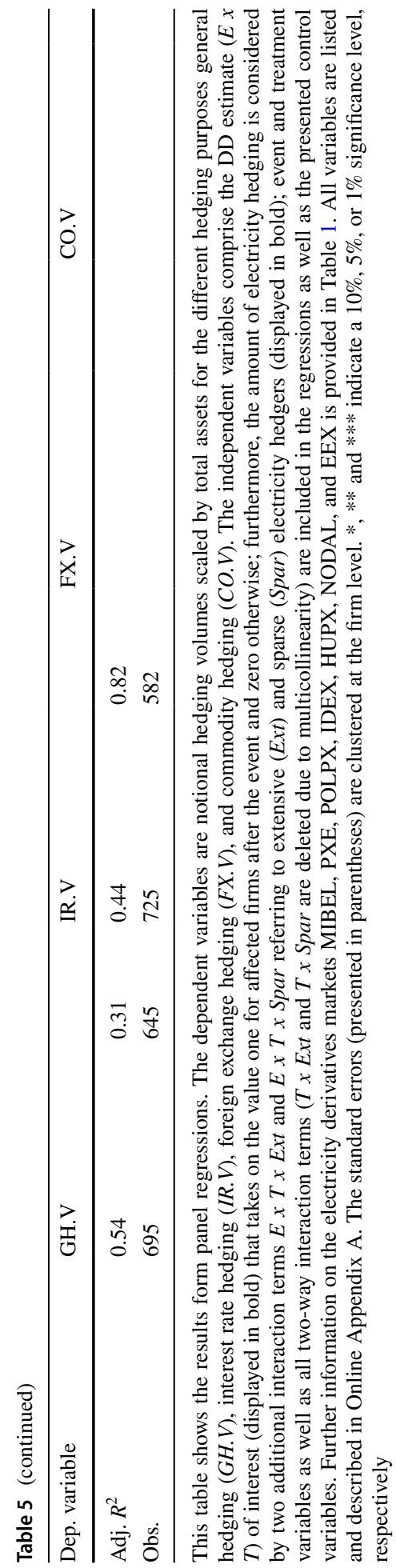


specifically substitutes IR hedging. This might imply that output hedging reduces earnings volatility, which in turn increases the availability of internal funds and thereby reduces the demand for IR hedging. Additionally, FX hedging volumes increase with output hedging $\left(\beta_{F X V}^{E x T}=0.049\right)$. However, this effect is not unique, since especially extensive EL hedgers tend to reduce prior FX hedging volumes by electricity derivatives $\left(\beta_{F X . V}^{E x T x E x t}=-0.272\right)$. On the one hand, firms might use a combination of domestic electricity derivatives and FX derivatives to hedge their foreign sales, which might justify the overall positive effect for FX hedging volumes. On the other hand, extensive output hedgers might reach an intended earnings stability using electricity derivatives, while substituting their FX hedging volumes. One further reason for this negative effect might be, that firms use domestic electricity derivatives instead of a formerly proxy-hedge consisting of commodity derivatives (for example, oil derivatives usually invoiced in US dollar) and FX derivatives. For commodity hedging, the DDD estimates show that the corresponding hedging volumes (in total) increase for sparse $\left(\beta_{C O . V}^{E x T x S p a r}=0.060\right)$ and extensive EL hedgers $\left(\beta_{C O . V}^{\text {ExTxEx }}=0.215\right)$. These effects are expected to stem from increased EL hedging volumes and are probably linked to the possibility offered with the market creation to hedge separately the electricity and the commodity sides and not only the spread.

To sum up the results for hedging behavior, an external event in derivatives markets access has a statistically significant positive impact on the decision to hedge. This implies that derivatives market access is an important factor in explaining derivatives usage and thereby the results confirm the findings of the previous work by Bartram et al. (2009). With the findings from the probit regressions, $H 1$ can be confirmed: introduction of a domestic electricity market influences positively the decision to hedge FX and EL. Additionally, the separate hedging of electricity risks coincides with reduction of other hedging positions $(G H, I R$, and $F X)$ due to substitution effects. But because the creation of a domestic electricity market enables firms to hedge separately input and output risks we observe an increase of hedging volume of commodities. Hence, we are able to accept $H 2$, which postulates that a new electricity market influences the hedging volumes.

\subsection{Risk exposure}

Table 6 presents the results from the analysis of risk exposure. Therein, the impact of electricity derivatives market introductions on risk betas (sensitivities) of a firm is investigated.

The results show that, since electricity output hedging has several spillover effects on other hedging activities, output hedging also has a major impact on firm value sensitivities to market risk, IR risk, and FX risk, but only a minor effect on other commodity risks (oil, gas, and coal). For market risk, the DD estimate shows an overall negative effect $\left(\beta_{M}^{E x T}=-0.169\right)$, while this negative effect is diminished for sparse EL hedgers $\left(\beta_{M}^{\text {ExTxSpar }}=0.216\right)$. Accordingly, EL hedging significantly reduces a firm's market risk exposure. Hence, EL hedging enables a firm to hedge a major part of its market risk covered by its electricity production. For IR risk, we observe a positive effect for the DD estimate $\left(\beta_{I R}^{E x T}=0.026\right)$ and for the DDD estimate of sparse hedgers $\left(\beta_{I R}^{E x T x S p a r}=0.030\right)$. Hence, EL hedging leads to an increasing IR exposure, which might stem from lower IR hedging volumes and higher debt capacities (Graham and Rogers 2002) achieved by EL hedging. Considering the DD estimate for FX risk $\left(\beta_{F X}^{E x T}=-0.181\right)$ and the corresponding DDD estimates for extensive $\left(\beta_{F X}^{E x T x E x t}=0.294\right)$ or sparse EL hedgers $\left(\beta_{F X}^{E x T x S p a r}=0.260\right)$, the total effects are positive for both groups. Following the analyses of FX hedging volumes, one reason might be reduced FX hedging activities. 


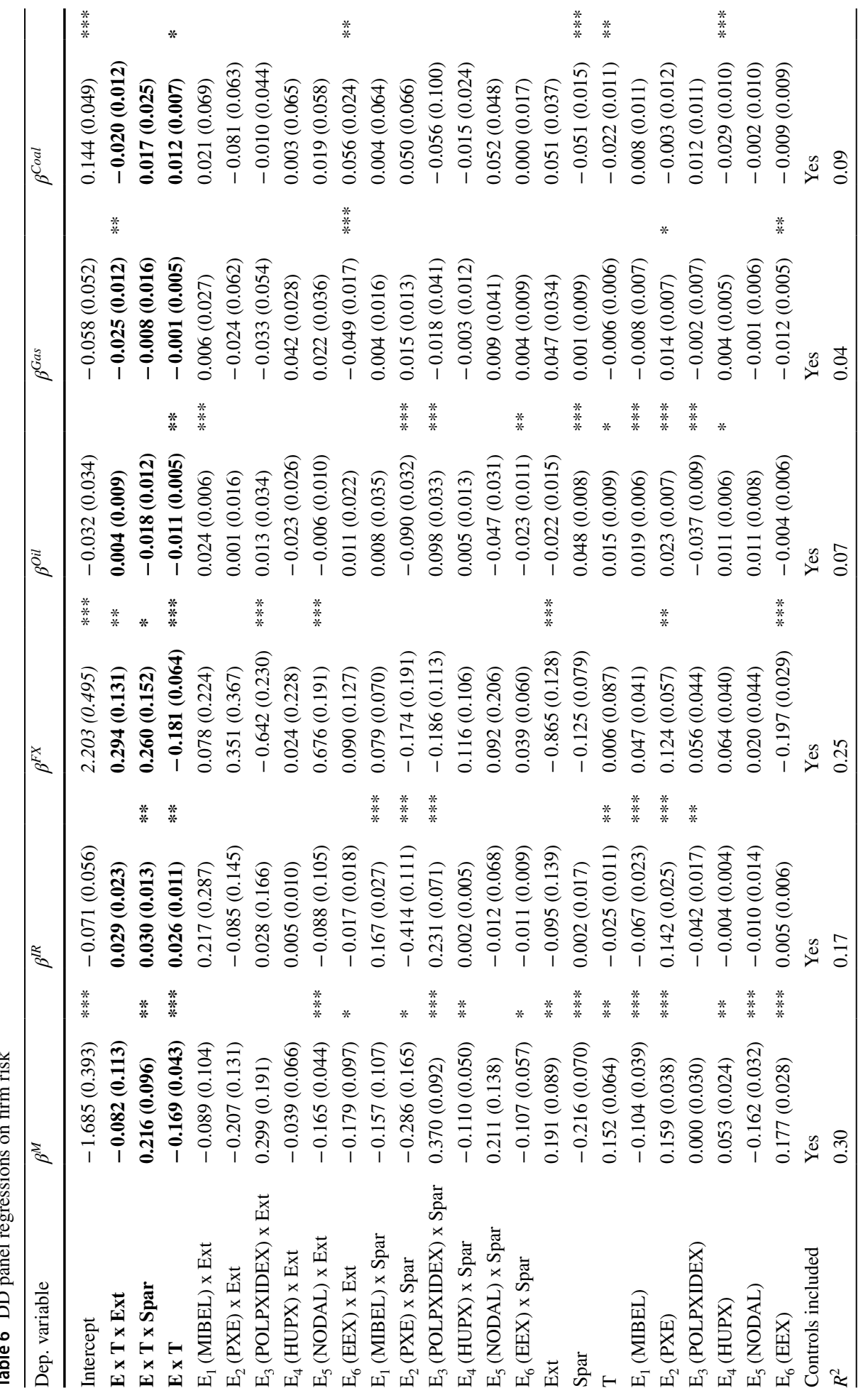




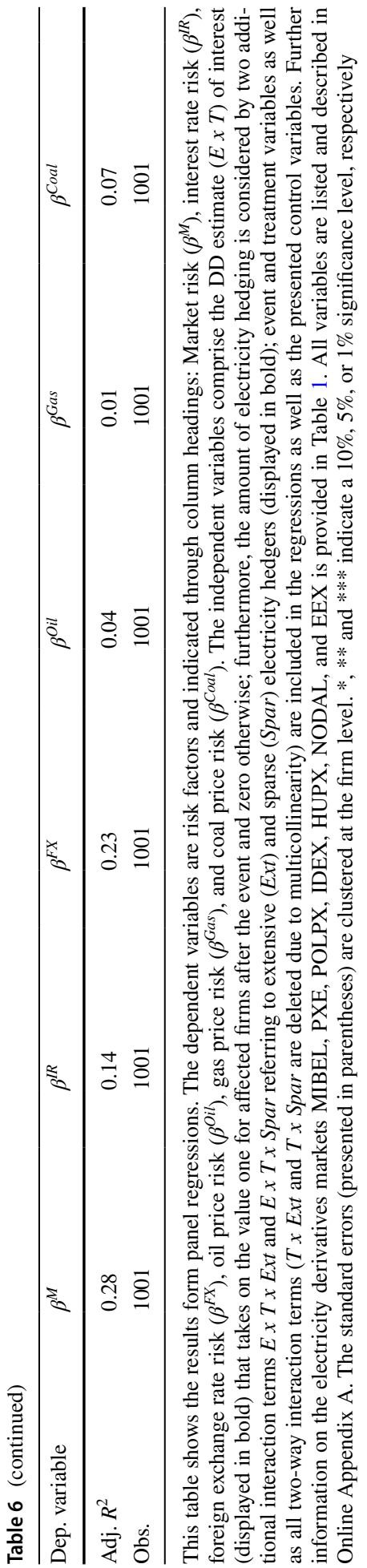


Consequently, output hedgers are more sensitive to FX risks. Among the commodity risks, we only observe a mitigating effect for the oil price risk $\left(\beta_{O i l}^{E x T}=-0.011\right)$ and for gas price risk particularly for extensive hedgers $\left(\beta_{G a s}^{E x T x E x t}=-0.016\right)$. In contrast, the effect is marginally positive for coal price risk $\left(\beta_{\text {Coal }}^{E x T}=0.012\right)$.

Overall, the results confirm an impact of electricity derivatives market introductions on various risk factors and, thus, support $H 3$. However, the effects differ across the various risk factors, which depends on the varying developments of the hedging volumes for the various purposes due to the introduction of electricity derivatives markets.

\subsection{Financing and investment}

Subsequently, the effects of electricity output hedging on leverage ratio and capital expenditure are examined. The corresponding results are displayed in Table 7.

As proposed in several articles, firms might jointly take decisions concerning corporate hedging, financing, and investment (Froot et al. 1993; Lin et al. 2008; Ross 1977). Concerning a firm's financing decision, we confirm a positive impact of electricity output hedging on leverage ratio. This result becomes apparent through the statistically significant regression coefficients of the DD estimate $\left(\beta_{\text {Leverage ratio }}^{\text {ExT }}=0.239\right)$ and the DDD estimates $\left(\beta_{\text {Leverage ratio }}^{\text {ExTxSpar }}=0.921, \beta_{\text {Leverage ratio }}^{\text {ExTExt }}=0.762\right)$. Accordingly, higher volumes of EL hedging significantly increase the use of debt financing. This result confirms $\mathrm{H} 4$ and provides evidence for the fact that output hedging increases debt capacities following the works by Graham and Rogers (2002), Leland (1998), Lin et al. (2008), and Stulz (1996) and enhances the willingness of outside creditors to invest.

For the effect of electricity output hedging on a firm's investment decision, we observe a statistically significant negative effect for the DD estimate $\left(\beta_{\text {Capital expenditure }}^{\text {ExT }}=-0.013\right)$ and positive effects for the DDD estimates $\left(\beta_{\text {Capital expenditure }}^{\text {ExTxpar }}=0.022, \beta_{\text {Capital expenditure }}^{\text {ExTxExt }}=0.013\right)$. For this reason, we are able to confirm H5. Overall, the effects on capital expenditure are, however, classified as economically marginal. This also holds for the total DD effects, which are the sum of the DD estimate $(E x T)$ and the respective DDD estimate, and which are positive but close to zero.

In conclusion, the regression results for leverage ratio and capital expenditure show that the usage of electricity derivatives increases the use of debt financing as proposed by $H 4$. Furthermore, the introduction of electricity derivatives markets has a marginal positive impact on a firm's investment behavior as stated in $H 5$.

\subsection{Firm value}

As the results in Table 7 further show, there is no impact of the introduction of electricity derivatives markets on firm values. These results might be seen as an indication towards the managerial utility maximization theory, which assumes that firm values are independent of corporate hedging decisions. Hence, the results provide no evidence for a positive (Allayannis and Weston 2001) or negative (de Angelis and Ravid 2017) value effect and $H 6$ cannot be accepted. In contrast, these results are in line with, among others, Jin and Jorion (2006). 
Table 7 DD panel regressions on financing, investment, and firm value

\begin{tabular}{|c|c|c|c|c|c|c|}
\hline \multirow{2}{*}{$\frac{\text { Dep. variable }}{\text { Intercept }}$} & \multicolumn{2}{|l|}{ Leverage ratio } & \multicolumn{2}{|c|}{ Capital expenditure } & \multicolumn{2}{|l|}{ Tobin's Q } \\
\hline & $4.709(1.580)$ & $* * *$ & $0.062(0.024)$ & $* *$ & $1.295(0.264)$ & $* * *$ \\
\hline E $\times$ T x Ext & $0.762(0.409)$ & $*$ & $0.013(0.006)$ & $* *$ & $-0.046(0.112)$ & \\
\hline E x T x Spar & $0.921(0.343)$ & $* * *$ & $0.022(0.006)$ & $* * *$ & $0.012(0.068)$ & \\
\hline $\mathbf{E} \times \mathbf{T}$ & $0.239(0.126)$ & $*$ & $-0.013(0.004)$ & $* * *$ & $0.041(0.029)$ & \\
\hline $\mathrm{E}_{1}(\mathrm{MIBEL}) \mathrm{x} \mathrm{Ext}$ & $0.439(0.813)$ & & $0.016(0.016)$ & & $0.009(0.182)$ & \\
\hline $\mathrm{E}_{2}(\mathrm{PXE}) \mathrm{x} \mathrm{Ext}$ & $0.063(0.856)$ & & $0.002(0.015)$ & & $0.167(0.228)$ & \\
\hline $\mathrm{E}_{3}(\mathrm{POLPXIDEX}) \mathrm{x}$ Ext & $0.182(0.522)$ & & $0.004(0.008)$ & & $-0.092(0.184)$ & \\
\hline $\mathrm{E}_{4}(\mathrm{HUPX}) \times \mathrm{Ext}$ & $-0.784(0.744)$ & & $0.009(0.007)$ & & $0.028(0.132)$ & \\
\hline $\mathrm{E}_{5}(\mathrm{NODAL}) \mathrm{x} \mathrm{Ext}$ & $-0.083(0.766)$ & & $-0.005(0.008)$ & & $-0.051(0.137)$ & \\
\hline $\mathrm{E}_{1}(\mathrm{MIBEL}) \mathrm{x}$ Spar & $0.128(0.492)$ & & $-0.014(0.272)$ & & $0.078(4.191)$ & \\
\hline $\mathrm{E}_{2}(\mathrm{PXE}) \times \mathrm{Spar}$ & $-0.326(0.817)$ & & $-0.022(0.020)$ & & $0.094(0.270)$ & \\
\hline $\mathrm{E}_{3}(\mathrm{POLPXIDEX}) \times \mathrm{Spar}$ & $0.266(0.883)$ & & $0.003(0.011)$ & & $-0.056(0.289)$ & \\
\hline $\mathrm{E}_{4}(\mathrm{HUPX}) \mathrm{x}$ Spar & $0.201(0.440)$ & & $0.002(0.012)$ & & $-0.072(0.144)$ & \\
\hline $\mathrm{E}_{5}(\mathrm{NODAL}) \times \mathrm{Spar}$ & $-0.261(0.603)$ & & $0.034(0.015)$ & $* *$ & $-0.061(0.174)$ & \\
\hline $\mathrm{E}_{6}(\mathrm{EEX}) \times \mathrm{Spar}$ & $-0.039(0.255)$ & & $-0.004(0.006)$ & & $-0.084(0.049)$ & $*$ \\
\hline Ext & $-1.647(0.424)$ & $* * *$ & $-0.043(0.010)$ & $* * *$ & $0.014(0.110)$ & \\
\hline Spar & $-1.423(4.928)$ & & $-0.017(0.271)$ & & $0.058(4.191)$ & \\
\hline $\mathrm{T}$ & $-1.439(0.291)$ & $* * *$ & $0.007(0.006)$ & & $-0.109(0.047)$ & $* *$ \\
\hline $\mathrm{E}_{1}$ (MIBEL) & $-0.185(0.228)$ & & $-0.004(0.009)$ & & $0.085(0.039)$ & $* *$ \\
\hline $\mathrm{E}_{2}(\mathrm{PXE})$ & $0.022(0.155)$ & & $0.004(0.005)$ & & $-0.006(0.045)$ & \\
\hline $\mathrm{E}_{3}$ (POLPXIDEX) & $0.078(0.190)$ & & $0.012(0.005)$ & $* *$ & $-0.168(0.040)$ & $* * *$ \\
\hline $\mathrm{E}_{4}(\mathrm{HUPX})$ & $-0.151(0.189)$ & & $-0.008(0.005)$ & $*$ & $0.000(0.030)$ & \\
\hline $\mathrm{E}_{5}(\mathrm{NODAL})$ & $-0.024(0.233)$ & & $0.006(0.006)$ & & $0.002(0.040)$ & \\
\hline $\mathrm{E}_{6}(\mathrm{EEX})$ & $0.234(0.156)$ & & $-0.002(0.003)$ & & $0.059(0.020)$ & $* * *$ \\
\hline Controls included & Yes & & Yes & & Yes & \\
\hline$R^{2}$ & 0.14 & & 0.12 & & 0.30 & \\
\hline Adj. $R^{2}$ & 0.11 & & 0.10 & & 0.28 & \\
\hline Obs. & 1001 & & 1001 & & 1001 & \\
\hline
\end{tabular}

This table shows the results form panel regression. The dependent variable is leverage, capital expenditure, and Tobin's Q respectively. The independent variables comprise the DD estimate $(E x T)$ of interest (displayed in bold) that takes on the value one for affected firms after the event and zero otherwise; furthermore, the amount of electricity hedging is considered by two additional interaction terms Ex $T x E x t$ and $E x T x$ Spar referring to extensive (Ext) and sparse (Spar) electricity hedgers (displayed in bold); event and treatment variables as well as all two-way interaction terms $\left[T x E x t, T x \operatorname{Spar}\right.$, and $E_{6}(E E X) x E x t$ are deleted due to multicollinearity] are included in the regressions as well as the presented control variables. Further information on the electricity derivatives markets MIBEL, PXE, POLPX, IDEX, HUPX, NODAL, and EEX is provided in Table 1. All variables are listed and described in Online Appendix A. The standard errors (presented in parentheses) are clustered at the firm level. *, ** and *** indicate a $10 \%, 5 \%$, or $1 \%$ significance level, respectively

\subsection{Robustness tests}

In order to examine the robustness of the results, we perform several additional tests to take the following issues into account. (1) One crucial aspect in DD analysis, is the parallel trends assumption. Since this assumption cannot be tested directly (Roberts and Whited 
2013), we apply the suggested falsification test in the form of a placebo event analysis. ${ }^{6}$ Accordingly, we repeat the DD analysis on the pre-event year t-3. In this manner, the placebo event analysis tests if the observed changes in hedging behavior, risk exposure, leverage ratio, investments, and firm value are reasonably due to the treatment instead of another effect. (2) Although, we follow the approach by Bakke et al. (2016) when analyzing the hedge ratios, there might be serious groupings of observations around zero and one in our case. Consequently, we perform a tobit model with censoring at zero and one using robust Huber/White standard errors following, among others, Haushalter (2000) and Lievenbrück and Schmid (2014). (3) The decision of how much to hedge is inseparable from the decision to hedge, since notional hedging volumes greater than zero are only observable if a firm decides to hedge. Furthermore, the decision to hedge is not random (Pincus and Rajgopal 2002). For this reason, the notional values of hedging are only observable for a subset of the sample, which is built on a decision that is affected by influencing variables. In order to consider this issue (Choi et al. 2015; Pincus and Rajgopal 2002), commonly referred to as sample selection bias, a Heckman correction is employed (Heckman 1979). In the first stage, we use the existence of hedging activity as dependent variable, modeled as a dummy variable. The dummy variable takes on the value one for a firm at time $t$, if the firm is classified as hedger in $\mathrm{t}$ or $\mathrm{t}-1$, and cash flows from hedging positions are non-zero in $\mathrm{t}-1$ (Adam et al. 2015). As predictors, the selection equation contains all firm characteristics covered by the control variables as well as an indicator variable, which takes the value one, if a firm applies international accounting standards (IFRS or US-GAAP) (Lievenbrück and Schmid 2014), which is drawn from annual reports. The regressions are carried out using robust Huber/ White standard errors. (4) The analyses of financing, investment, and firm value are further carried out by treating these variables as endogenous predictors in the respective variables. Therefore, a two-stage least squares approach (with clustered errors on the firm value in the second stage) is applied to consider potential endogeneity among these variables following Lin et al. (2010), Magee (2013), and Pincus and Rajgopal (2002). As instruments in the first stage, the dependent variable is used with a one-year and two-year lag. This is motivated by the fact that these variables tend to be rather sticky. (5) All reported regressions are further duplicated using lagged events. In this regard, all dummy variables $E_{t}^{m}$ (including the associated interaction terms) are constructed with a 1 year lag. This procedure should provide insights into the temporal structure of the effects and reveal if there are anticipation effects in our dependent variables in advance to the actual introduction of the derivatives markets. (6) Instead of using clustered standard errors on the firm level, all reported regressions are further re-calculated using robust Huber/White standard errors, and robust Huber/White standard errors clustered at the firm level. (7) Beside, financing, investment, and firm value are further only analyzed for North American firms as well as for large firms (whose average firm size across the observation period is above the overall median firm size). (8) Finally, we also analyze premiums of credit default swaps (5 years) in order to reveal the impact on debt prices in addition to debt quantities.

All robustness tests confirm the results of our baseline models. Especially, the placebo event analysis (see Online Appendix F) does not reveal any alternative pre-event effects

\footnotetext{
6 The complexity in testing the parallel trends assumption in this paper compared to a usual DD analysis is that there are multiple events instead of one single event, and that for some observations the event already happened before the observation period. To reach sharp test results, we restrict the event set to market introductions taking place within the observation period. Furthermore, we exclude observations from countries, in which electricity derivatives could be traded before the observation period.
} 
for our core findings. This is reflected by the insignificant test results for the interaction term $\left(E^{t-3} x T\right)$ included in the regression models. Among the further robustness tests, the heckit models provide no evidence for the presence of sample selection. When applying the lagged event variables, the effects are diminished. Consequently, we conclude that firms primarily adopt their hedging strategy to restructurings in financial derivatives markets in the year of the restructuring, as assumed in our baseline models. Our robustness tests further confirm that the main results for financing, investment, and firm value especially hold for North American firms as well as for large firms. In order to distinguish between the effects on debt levels compared to debt prices, also premiums of credit default swaps are analyzed. The results reveal, that the derivatives market introduction only has an impact on debt levels, not on debt prices. The results of the robustness tests for the DD estimates of interest $(E x T, E x T \times S p a r$, and $E x T \times E x t)$ are summed up in Online Appendix G.

\section{Conclusion}

Literature is largely silent on the consequences and interactions of corporate hedging activities in the presence of a multi-risk exposure. This study addresses these questions by analyzing corporate hedging activities in the electric utility industry. The introductions of electricity derivatives markets create a unique setting for the analysis of corporate hedging practices of electric utility. The aim of this study is to consult these financial innovations as a new measure of EL hedging. In contrast to prior research focusing on endogenous variation in hedging behavior driven by internal corporate decisions, this approach uses a quasiexogenous change in the variability of electricity derivatives. Based on a set of 16 events, the hedging behavior, risk exposure, financing and investment decisions, and firm values are analyzed based on a sample of 159 firms form 40 countries for the years 2005-2015.

The results show that electric utilities generally favor domestic markets for trading electricity derivatives, which might be reduced to their usual high market power and the related good predictability of electricity prices. As a consequence, electricity output hedging eliminates a major part of overall market risk. Further, we identify several spillover effects of electricity output hedging: The sensitivities to input commodity prices decrease, while the sensitivities to foreign exchange rates and interest rates increase. Furthermore, electricity output hedging increases debt capacities and the availability of internal funds. Overall, the access to electricity derivatives markets is identified as a crucial country-level determinant. Our results are highly relevant for electric utility firms, but also for market operators and policy makers. Opposed to the findings from Fernandes (2011) stating that financing practices converge across countries over time, the presence of electricity derivatives markets is a crucial cross-country difference, which leads to a global divergence of financing policies. Let's stress that electricity market is a highly capital intensive sector and therefore, the introduction of efficient electricity derivatives markets should help electricity utilities to be able to face the massive investments they are required to perform in the energy transition context. Future research might cover potential selective-hedging or speculation effects (Adam and Fernando 2006; Adam et al. 2015) in the case of output hedging for an industry hedging diverse risks on the input and output side.

Acknowledgements Open access funding provided by Projekt DEAL. We gratefully thank all seminar participants at the 35th Annual Conference of the French Finance Association (AFFI) for their helpful comments and suggestions. This work was supported by the German-French University 
(Deutsch-Französische Hochschule/Université franco-allemande) Saarbrücken, Germany [Grant Number RS-04-17_2017_2018_2019].

Open Access This article is licensed under a Creative Commons Attribution 4.0 International License, which permits use, sharing, adaptation, distribution and reproduction in any medium or format, as long as you give appropriate credit to the original author(s) and the source, provide a link to the Creative Commons licence, and indicate if changes were made. The images or other third party material in this article are included in the article's Creative Commons licence, unless indicated otherwise in a credit line to the material. If material is not included in the article's Creative Commons licence and your intended use is not permitted by statutory regulation or exceeds the permitted use, you will need to obtain permission directly from the copyright holder. To view a copy of this licence, visit http://creativecommons.org/licenses/by/4.0/.

\section{References}

Adam TR (2002) Do firms use derivatives to reduce their dependence on external capital markets? Rev Finance (former European Finance Review) 6:163-187. https://doi.org/10.1023/A:1020121007127

Adam TR, Fernando CS (2006) Hedging, speculation, and shareholder value. J Financ Econ 81:283-309. https://doi.org/10.1016/j.jfineco.2005.03.014

Adam TR, Fernando CS, Golubeva E (2015) Managerial overconfidence and corporate risk management. J Bank Finance 60:195-208. https://doi.org/10.1016/j.jbankfin.2015.07.013

Aïd R (2015) Electricity derivatives, 1st edn. Springer International Publishing, Cham

Alexander C, Prokopczuk M, Sumawong A (2013) The (de)merits of minimum-variance hedging: application to the crack spread. Energy Econ 36:698-707. https://doi.org/10.1016/j.eneco.2012.11.016

Allayannis G, Weston JP (2001) The use of foreign currency derivatives and firm market value. Rev Financ Stud 14:243-276. https://doi.org/10.1093/rfs/14.1.243

Angrist JD, Krueger AB (1999) Empirical strategies in labor economics. In: Ashenfelter OC, Card D (eds) Handbook of labor economics, vol 3, 1st edn. Elsevier Science, Amsterdam, pp 1277-1366

Aretz K, Bartram SM (2010) Corporate hedging and shareholder value. J Financ Res 33:317-371. https:// doi.org/10.1111/j.1475-6803.2010.01278.x

Arora V, Lieskovsky J (2014) Electricity use as an indicator of U.S. Economic activity. U.S. Energy Information Administration. Washington, DC

Arnold MM, Rathgeber AW, Stöckl S (2014) Determinants of corporate hedging: a (statistical) meta-analysis. Q Rev Econ Finance 54:443-458. https://doi.org/10.1016/j.qref.2014.05.002

Bakke T-E, Mahmudi H, Fernando CS, Salas JM (2016) The causal effect of option pay on corporate risk management. J Financ Econ 120:623-643. https://doi.org/10.1016/j.jfineco.2016.02.007

Bartram SM (2019) Corporate hedging and speculation with derivatives. J Corp Finance 57:9-34. https:// doi.org/10.1016/j.jcorpfin.2017.09.023

Bartram SM, Brown GW, Fehle FR (2009) International evidence on financial derivatives usage. Financ Manage 28:185-206. https://doi.org/10.1111/j.1755-053X.2009.01033.X

Batra RN, Donnenfeld S, Hadar J (1982) Hedging behavior by multinational firms. J Int Bus Stud 13:59-70. https://doi.org/10.1057/palgrave.jibs.8490558

Bessembinder H (1991) Forward contracts and firm value: investment incentive and contracting effects. J Financ Quant Anal 26:519-532. https://doi.org/10.2307/2331409

Bierbrauer M, Menn C, Rachev ST, Trück S (2007) Spot and derivative pricing in the EEX power market. J Bank Finance 31:3462-3485. https://doi.org/10.1016/j.jbankfin.2007.04.011

Brunzell T, Hansson M, Liljeblom E (2011) The use of derivatives in Nordic firms. Eur J Finance 17:355376. https://doi.org/10.1080/1351847X.2010.543836

Búa MV, González LO, López SF, Santomil PD (2013) Is value creation consistent with currency hedging? Eur J Finance 21:912-945. https://doi.org/10.1080/1351847X.2013.773262

Campello M, Lin C, Ma Y, Zou H (2011) The real and financial implications of corporate hedging. J Finance 66:1615-1647. https://doi.org/10.1111/j.1540-6261.2011.01683.x

Carter DA, Rogers DA, Simkins BJ (2006) Does hedging affect firm value? Evidence from the US airline industry. Financ Manage 35:53-86. https://doi.org/10.1111/j.1755-053X.2006.tb00131.x

Carter DA, Rogers DA, Simkins BJ, Treanor SD (2017) A review of the literature on commodity risk management. J Commod Mark 8:1-17. https://doi.org/10.1016/j.jcomm.2017.08.002

Casassus J, Liu P, Tang K (2012) Economic linkages, relative scarcity, and commodity futures returns. Rev Financ Stud 26:1324-1362. https://doi.org/10.1093/rfs/hhs127 
Choi JJ, Elyasiani E, Kopecky KJ (1992) The sensitivity of bank stock returns to market, interest and exchange rate risks. J Bank Finance 16:983-1004. https://doi.org/10.1016/0378-4266(92)90036-Y

Choi JJ, Mao CX, Upadhyay AD (2015) Earnings management and derivative hedging with fair valuation: evidence from the effects of FAS 133. Account Rev 90:1437-1467. https://doi.org/10.2308/accr-50972

de Angelis D, Ravid SA (2017) Input hedging, output hedging, and market power. J Econ Manag Strategy 26:123-151. https://doi.org/10.1111/jems.12180

DeMarzo PM, Duffie D (1995) Corporate incentives for hedging and hedge accounting. Rev Financ Stud 8:743-771. https://doi.org/10.1093/rfs/8.3.743

Dempster MAH, Medova E, Tang K (2008) Long term spread option valuation and hedging. J Bank Finance 32:2530-2540. https://doi.org/10.1016/j.jbankfin.2008.04.004

Deng S-J, Oren SS (2006) Electricity derivatives and risk management. Energy 31:940-953. https://doi. org/10.1016/j.energy.2005.02.015

Deng S-J, Johnson B, Sogomonian A (2001) Exotic electricity options and the valuation of electricity generation and transmission assets. Decis Support Syst 30:383-392. https://doi.org/10.1016/S0167 $-9236(00) 00112-3$

Dionne G, Gueyie J-P, Mnasri M (2018) Dynamic corporate risk management: motivations and real implications. J Bank Finance 95:97-111. https://doi.org/10.1016/j.jbankfin.2017.08.011

Fernandes N (2011) Global convergence of financing policies: evidence for emerging-market firms. J Int Bus Stud 42:1043-1059. https://doi.org/10.1057/jibs.2011.27

Froot KA, Scharfstein DS, Stein JC (1993) Risk management: coordinating corporate investment and financing policies. J Finance 48:1629-1658. https://doi.org/10.1111/j.1540-6261.1993.tb05123.x

Geman H (ed) (2009) Risk management in commodity markets: from shipping to agriculturals and energy, 1st edn. Wiley, Chichester

Geyer-Klingeberg J, Hang M, Rathgeber AW, Stöckl S (2018) What do we really know about corporate hedging? A meta-analytical study. Bus Res 11:1-31. https://doi.org/10.1007/s40685-017-0052-0

Geyer-Klingeberg J, Hang M, Rathgeber AW (2019) What drives financial hedging? A meta-regression analysis of corporate hedging determinants. Int Rev Financ Anal 61:203-221. https://doi.org/10.1016/j. irfa.2018.11.006

Ghosh A (1996) Cross-hedging foreign currency risk: empirical evidence from an error correction model. Rev Quant Financ Account 6:223-231. https://doi.org/10.1007/BF00245181

Gilje EP, Taillard JP (2017) Does hedging affect firm value? Evidence from a natural experiment. Rev Financ Stud 30:4083-4132. https://doi.org/10.1093/rfs/hhx069

Graham JR, Rogers DA (2002) Do firms hedge in response to tax incentives. J Finance 57:815-839. https:// doi.org/10.1111/1540-6261.00443

Hahnenstein L, Röder K (2007) Who hedges more when leverage is endogenous? A testable theory of corporate risk management under general distributional conditions. Rev Quant Financ Account 28:353391. https://doi.org/10.1007/s11156-007-0017-z

Haushalter DG (2000) Financing policy, basis risk, and corporate hedging: evidence from oil and gas producers. J Finance 55:107-152. https://doi.org/10.1111/0022-1082.00202

Hausman JA (1978) Specification tests in econometrics. Econometrica 46(6):1251-1271

Heckman JJ (1979) Sample selection bias as a specification error. Econometrica 47:153-161. https://doi. org/10.2307/1912352

Hedgeweek (2020) EEX power derivatives market volume up 32 per cent year-on-year in December. https ://www.hedgeweek.com/2020/01/03/281633/eex-power-derivatives-market-volume-32-cent-year-yeardecember. Accessed 21 Jan 2020

Hong L, Li Y, Xie K, Yan CJ (2020) On the market timing of hedging: evidence from U.S. oil and gas producers. Rev Quant Financ Account 54:297-334. https://doi.org/10.1007/s11156-019-00790-y

Jamil F, Ahmad E (2010) The relationship between electricity consumption, electricity prices and GDP in Pakistan. Energy Policy 38:6016-6025. https://doi.org/10.1016/j.enpol.2010.05.057

Jensen MC, Meckling WH (1976) Theory of the firm: managerial behavior, agency costs and ownership structure. J Financ Econ 3:305-360. https://doi.org/10.1016/0304-405X(76)90026-X

Jin Y, Jorion P (2006) Firm value and hedging: evidence from U.S. oil and gas producers. J Finance 61:893919. https://doi.org/10.1111/j.1540-6261.2006.00858.x

Krajcar S, Sprčić MD, Sprčić P (2008) The influence of risk management theories on the use of derivatives in the electronic power industry. J Energy 57:64-87

Kumar P, Rabinovitch R (2013) CEO entrenchment and corporate hedging: evidence from the oil and gas industry. J Financ Quant Anal 48:887-917. https://doi.org/10.1017/S0022109013000276

Leland HE (1998) Agency costs, risk management, and capital structure. J Finance 53:1213-1243. https:// doi.org/10.1111/0022-1082.00051 
Li L, Kleindorfer PR (2009) On hedging spark spread options in electricity markets. Risk Decis Anal 1:211-220. https://doi.org/10.3233/RDA-2009-0018

Lievenbrück M, Schmid T (2014) Why do firms (not) hedge?-novel evidence on cultural influence. J Corp Finance 25:92-106. https://doi.org/10.1016/j.jcorpfin.2013.10.010

Lin C-M, Phillips RD, Smith SD (2008) Hedging, financing, and investment decisions: theory and empirical tests. J Bank Finance 32:1566-1582. https://doi.org/10.1016/j.jbankfin.2007.11.014

Lin J-SB, Pantzalis C, Park JC (2010) Corporate hedging policy and equity mispricing. Financ Rev 45:803824. https://doi.org/10.1111/j.1540-6288.2010.00272.x

Lookman A (2004) Does hedging increase firm value? evidence from oil and gas producing firms. Carnegie Mellon University. Pittsburgh, PA (working paper)

Magee S (2013) The effect of foreign currency hedging on the probability of financial distress. Account Finance 53:1107-1127. https://doi.org/10.1111/j.1467-629x.2012.00489.x

Massa M, Zhang L (2018) Does corporate hedging attract foreign institutional investors? Evidence from international firms. J Int Bus Stud 49:605-632. https://doi.org/10.1057/s41267-017-0140-6

Mayer K, Trück S (2018) Electricity markets around the world. J Commod Mark 9:77-100. https://doi. org/10.1016/j.jcomm.2018.02.001

Meyer BD (1995) Natural and quasi-experiments in economics. J Bus Econ Stat 13:151. https://doi. org/10.2307/1392369

Mian SL (1996) Evidence on corporate hedging policy. J Financ Quant Anal 31:419-439. https://doi. org/10.2307/2331399

Mnasri M, Dionne G, Gueyie J-P (2017) The use of nonlinear hedging strategies by US oil producers: motivations and implications. Energy Econ 63:348-364. https://doi.org/10.1016/j.eneco.2017.02.003

Murat A, Tokat E (2009) Forecasting oil price movements with crack spread futures. Energy Econ 31:8590. https://doi.org/10.1016/j.eneco.2008.07.008

Myers SC (1977) Determinants of corporate borrowing. J Financ Econ 5:147-175. https://doi. org/10.1016/0304-405X(77)90015-0

Nance DR, Smith CW Jr, Smithson CW (1993) On the determinants of corporate hedging. J Finance 48:267-284. https://doi.org/10.1111/j.1540-6261.1993.tb04709.x

Pérez-González F, Yun H (2013) Risk management and firm value: evidence from weather derivatives. J Finance 68:2143-2176. https://doi.org/10.1111/jofi.12061

Phan D, Nguyen H, Faff R (2014) Uncovering the asymmetric linkage between financial derivatives and firm value - the case of oil and gas exploration and production companies. Energy Econ 45:340-352. https://doi.org/10.1016/j.eneco.2014.07.018

Pincus M, Rajgopal S (2002) The interaction between accrual management and hedging: evidence from oil and gas firms. Account Rev 77:127-160. https://doi.org/10.2308/accr.2002.77.1.127

Roberts M, Whited T (2013) Endogeneity in empirical corporate finance. In: Constantinides GM, Harris M, Stulz RM (eds) Handbook of the economics of finance, 1st edn. North Holland, Oxford, pp 493-572

Ross SA (1977) The determination of financial structure: the incentive-signalling approach. Bell J Econ 8:23-40. https://doi.org/10.2307/3003485

Smith CW, Stulz RM (1985) The determinants of firms' hedging policies. J Financ Quant Anal 20:391-405. https://doi.org/10.2307/2330757

Stulz RM (1996) Rethinking risk management. J Appl Corp Finance 9:8-24. https://doi. org/10.1111/j.1745-6622.1996.tb00295.x

Stulz RM (2004) Should we fear derivatives? J Econ Perspect 18:173-192. https://doi.org/10.1257/08953 30042162359

Treanor SD, Rogers DA, Carter DA, Simkins BJ (2014) Exposure, hedging, and value: new evidence from the U.S. airline industry. Int Rev Financ Anal 34:200-211. https://doi.org/10.1016/j.irfa.2014.04.002

Tufano P (1996) Who manages risk? An empirical examination of risk management practices in the gold mining industry. J Finance 51:1097-1137. https://doi.org/10.1111/j.1540-6261.1996.tb04064.x

Wang X, Fan L (2011) The determinants of corporate hedging policies. Int J Bus Soc Sci 2:29-38

Willems B, Morbee J (2010) Market completeness: how options affect hedging and investments in the electricity sector. Energy Econ 32:786-795. https://doi.org/10.1016/j.eneco.2009.10.019

Publisher's Note Springer Nature remains neutral with regard to jurisdictional claims in published maps and institutional affiliations. 


\section{Affiliations}

Markus Hang ${ }^{1}$ (D) . Jerome Geyer-Klingeberg ${ }^{1} \cdot$ Andreas W. Rathgeber $^{1}$. Clémence Alasseur ${ }^{2}$. Lena Wichmann ${ }^{1}$

Jerome Geyer-Klingeberg

Jerome.Geyer-Klingeberg@mrm.uni-augsburg.de

Andreas W. Rathgeber

Andreas.Rathgeber@mrm.uni-augsburg.de

Clémence Alasseur

clemence.alasseur@edf.fr

Lena Wichmann

Lena.Wichmann@mrm.uni-augsburg.de

1 Institute of Materials Resource Management, University of Augsburg, Werner-von-Siemens-Straße 6, 86159 Augsburg, Germany

2 EDF R\&D - FIME Finance for Energy Market Research Center, 7 bd Gaspard Monge, 91120 Palaiseau, France 